\title{
Development Trend of Double Line Exhibition and New Demand for Exhibition Talents Under the Background of Digital Economy
}

\begin{abstract}
Hongxia $\mathrm{Wu}^{*}$
Beijing Vocational College of Finance and Commerce, Beijing, China

*Corresponding author. Email: wuhx@bjczy.edu.cn

ABSTRACT

Provides strategies for the development trend of offline exhibitions under the background of digital economy, as well as the upgrading and transformation of the operation mode of exhibition activities and countermeasures. Through the empirical research of the characteristics of the digital economy, the transformation of the offline exhibition mode under digital economy background, the transformation of the exhibition economic activities and the influence and correlation factors between these all discussing how to exert the adaptability of online exhibition under new situation, and the innovative training ideas and direction of exhibition professional talent cultivation under the demand of online exhibition reform.
\end{abstract}

Keywords: Digital Economy, Double Line Exhibition, Development Trend, New Demand for Talents.

\section{INTRODUCTION}

In recent years, "digital economy" has been more and more concerned by humanity. Under the background of digital economy and the global outbreak of COVID-19 in 2020, online exhibitions and "Online + offline" double line exhibition models have become the major trend of the development of MICE industry.

\section{THE DEVELOPMENT STATUS OF DOUBLE LINE EXHIBITION IN DIGITAL ECONOMY}

Since the "National Strategy of Large Data" was first proposed in 2015, policies to promote the development of the digital economy and digital transformation have been implemented and deepened. The Report Of China Digital Economy Development 2020released by the Foresight Industry Research Institute in August 2020 pointed out that the digital economy has become a new driving force for the highquality development of China's national economy, and the scale of the added value of the digital economy increased from 2.6 trillion Yuan in 2005 to 35.8 trillion Yuan in 2019. Meanwhile, the share of digital economy in GDP has increased year by year, from $14.2 \%$ in 2005 to $36.2 \%$ in $2019^{[1]}$. The newly released "China's Digital Road Report" predicts that from 2020 to 2025, the average annual growth rate of China's digital economy will remain at around $15 \%$. By 2025 , the size of the digital economy is expected to exceed 80 trillion Yuan; by 2030, the volume of China's digital economy will be expected to exceed one hundred trillion Yuan. It is expected that by 2025 , the digital economy will drive the employment of up to 379 million people nationwide [2].

In addition to the rapid development of the digital economy itself in the world, 2020 the new crown pneumonia epidemic spread in the global outbreak, the exhibition industry is one of the most severely affected areas, so the new crown epidemic also poses a challenge to the development of the digital economy in the exhibition industry. 2020 on April 13, the General Office of the Ministry of Commerce issued the "Notice on the work related to the innovation of exhibition service model and cultivation of new momentum in the development of the exhibition industry". In 2020, "from physical to virtual, from offline to online" has become the main development trend of the exhibition industry, and Huawei Events such as the Developer Conference and the 127th Canton Fair have kicked off the development of online exhibitions in China in 2020. The online exhibition has gradually been tested and recognized by the market. 
After 2020, it is inevitable for exhibitions to move from physical to virtual and from offline to online. However, according to a survey on exhibition practitioners, although more than $95 \%$ of respondents recognize the value of online exhibition, $60 \%$ of respondents have only heard of online exhibition and basically do not understand it, let alone how to operate and implement it. For China's digital exhibition industry, which has emerged under the backlash of the new crown epidemic, theoretical research is still relatively lacking. Through the search of literature and periodicals on China Knowledge Network, there are not many search results with the themes of "digital exhibition", "digital exhibition" and "digital conference", and the related literature is only 30 articles, including more than half of them are not so closely related. This shows that the research on exhibition economy in the context of digital economy needs to be strengthened. Among the existing research results, it mainly focuses on the research of online mode of exhibition, digital marketing and consumption mode of exhibition tourism service. According to Zhang Mowei, from the perspective of the exhibition industry, its development follows the pace of the Internet era. In developed countries in Europe and America, APP applications during conferences, exhibitions and large events have become the standard for exhibition activities, and the application of this new technology has an important impact on the organization mode of exhibitions as well as the value of exhibitions ${ }^{[3]}$. Zhang Ziyuan conducted a study on the marketing strategy of exhibition in the background of Internet era ${ }^{[4]}$. Zheng Jiaqianalyzed the digital revolution of "cloudbased exhibition" from Canton Fair ${ }^{[5]}$. Li Siyi et al. discussed the path of transformation and upgrading of the exhibition industry in the post-epidemic period based on the perspective of "Internet+" [6]. Jiang Xiaoyang et al. analyzed the driving force of the digital development of the exhibition industry in terms of the inevitable trend of the national policy to promote the digital economy and the power of advanced digital science and technology gathered by the exhibition itself [7]. Wu Yuwei et al. believe that network exhibition is impacting the public's consumption concept and consumption mode with an irreversible trend, and the network exhibition marketing method is bound to become the main marketing method of most enterprises in the future, and the performance will be steadily improved ${ }^{[8]}$. In addition, there are also discussions from the perspective of talent training, such as Tong Huabin et al. studied the strain strategy of talent training of conference and exhibition majors in the context of "Internet+" [9], and $\mathrm{Hu}$ Lingxia et al. studied the innovative talent training mode by taking conference and exhibition majors as an example ${ }^{[10]}$, and believed that "Internet+" new consumer industry is an important factor for the economy. "The new consumer industry is a basic requirement in the context of economic transformation, and the conference and exhibition organizers need to consider converting the offline conference and exhibition activities gathering a large amount of human, logistics and capital flow into information flow under the conditions of digital economy.

Despite having the above-mentioned relevant studies, due to the impact of the new crown epidemic sweeping the world in 2020, it is easy to see that the digital economy has put forward new requirements for the transformation and upgrading of the form, content, subject, object, participants and consumers of exhibition activities as well as the transformation of marketing strategies, and new challenges for practitioners in the operation, operation, management and service of online exhibition projects, as well as new topics for the cultivation of exhibition professionals.

\section{TRANSFORMATION OF THE OPERATION MODE OF TWO-LINE EXHIBITION IN THE CONTEXT OF DIGITAL ECONOMY}

\subsection{The Relationship between "Digital Exhibition" and "Online Exhibition" in the Background of Digital Economy}

Digital exhibition is not all about online exhibition. But compared with the concept of digital economy, online exhibition is not just a simple concept of moving real exhibition halls and booths to the network, but to break through the service function of not meeting but realizing real exhibition to promote trade caused by epidemic or other reasons, so that the new generation of information technology such as Internet, big data and artificial intelligence should be used to make the exhibition more convenient in terms of service object, service content, service scene, service form, service speed, service convenience, service safety, service experience, organization form, service platform, service time and service space. Therefore, we have to make fundamental changes to the real exhibition from service object, service content, service scene, service form, service speed, service convenience, service safety, service experience, organization form, service platform, service time, service space, etc. Therefore, the "digital exhibition" that makes all-round changes and transformations and breakthroughs in development concept, operation and management mode, business model, etc. is more in line with the concept of digital economy. The concept of "digital exhibition" is therefore more in line with the development needs of the digital economy era ${ }^{[11-12]}$.

Under the digital background, the online exhibition will realize the "24 $+7+365 "$ all-day and all-year round operation mode, the core content of the service is no longer just to build an exchange platform between exhibitors and purchasers, what's more important is to 
achieve instant digital services and timely communication between exhibitors and visitors, therefore, the service time only during the exhibition period will not meet the demand, what we need is allday and all-year round service. The resulting charging mode is no longer limited to the booth area or other services provided. For the online exhibition platform, it is necessary to produce valuable information and digital service which means much to customers in the context of digital economy, so that customers can rely on it. In this way, customers can be charged monthly, annually or according to the amount of data obtained, and then a new business model of digital exhibition enterprises can be generated.

\subsection{The Transformation of Online Exhibition Operation Mode in the Context of Digital Economy}

Although online exhibitions have to temporarily replace offline exhibitions due to objective reasons, however, in addition to its role as a trade promotion and platform, the exhibition industry also plays a role in enhancing the city's influence, driving the development of tourism and promoting consumption in the destination cities, Therefore, the full recovery of offline exhibitions is the symbol of the full recovery of the exhibition industry, and also the role of the exhibition industry in the national economy. After the test of COVID-19, in the digital economy era, with the continuous maturity of digital technology, the development of offline exhibitions to online exhibitions, the transformation and upgrading of the exhibition into digital and smart operation mode can hardly be avoided.

\subsection{Transformation of Online Exhibition Industry Chain in the Context of Digital Economy and Response to it}

In the process of transformation from traditional exhibitions to online and digital exhibitions, the exhibition industry chain will also change accordingly. In entity exhibition, exhibition hall, booth design and build, field service personnel and service facilities, and transportation business, suppliers, etc in simple online exhibition will be useless, instead of the industry chain will be a big shift, online exhibition platform, technical service enterprise, the related online exhibition service personnel and technical maintenance personnel, online financial service, network security and the operator will have larger demand, convention and exhibition industry chain upstream and downstream customers also can produce significant changes in structure and mode, so to complete the online exhibition and the transformation and upgrading of digital exhibition, All links of the relevant industrial chain should also be fully prepared to deal with these changes.

\section{DEVELOPMENT TREND OF TWO-LINE EXHIBITION IN THE BACKGROUND OF DIGITAL ECONOMY AND NEW DEMAND FOR EXHIBITION TALENTS}

\subsection{Future Development Trend of Two-line Exhibition}

Although the development of online exhibition forced by the epidemic is unstoppable, can online exhibition replace traditional offline exhibition activities? What is the direction of its future development? These questions still need to be studied. Reflecting the function of commerce, human-to-human communication, trust and commercial prudence, many functions of exhibition activities cannot be replaced by online exhibition, and exhibition activities can only be upgraded and transformed by going online, digitalization and wisdom under the force of the epidemic. Excellent exhibitions will provide greater assistance to the future online and offline integration development through the resources and digital advantages accumulated in this transformation and upgrading, which also becomes an important aspect of the competitiveness of future exhibitions.

\subsection{Construction and Improvement of Relevant Laws, Regulations and Systems}

In the process of traditional exhibition market management, corresponding management norms and legal regulations and systems have been formed. However, for online exhibitions, many contents are still brand new, and corresponding laws and regulations need to be formulated or improved to regulate the behaviours of exhibition enterprises, exhibitors, visitors and service providers, etc. On January 18, 2021, CCPIT Commercial Industry Committee released the group standard of "Online Exhibition Service Specification" (T/CCPITCSC 066-2021), which means that there will be relevant standards for online exhibition service specification. On-line exhibition service specification will have relevant standard reference. In addition, there are new issues in front of us, such as information security, identification of exhibitors, visitors and media personnel of online exhibition, facilitation of online negotiation or transaction, security of online financial service, access to and utilization of data and usage rights, and related service contents and technical standards of online exhibition. Therefore, relevant laws, regulations and systems need to be improved urgently, which has put forward new requirements for composite talents who know both exhibition and law. 


\subsection{New Demand for Exhibition Professionals with Digital Literacy}

With the development of information technology and the popularity of digital tools, digital literacy has become a necessary survival skill for citizens to participate in economic and social life in the 21st century. In order to meet the needs of the development of exhibition industry in digital economy, the cultivation of exhibition professionals with digital literacy needs to be accelerated urgently, especially the market is in urgent need of composite talents who can operate and operate online exhibitions combining technology and exhibition operation expertise. However, in the current training system of conference and exhibition professionals, there are temporarily fewer courses on online exhibition project operation, and how to timely respond to this market demand temporarily faces many difficulties, requiring modern information technology knowledge such as computer technology, network technology, artificial intelligence, 5G technology, big data and cloud computing as the background and core support, requiring technical knowledge of digital conference and exhibition operation and management knowledge. Therefore, it is possible to adopt crossborder cooperation and teacher team construction to innovate the cultivation mode of conference and exhibition professionals with digital literacy, so as to cultivate new professionals with digital literacy to meet the market demand.

\section{CONCLUSION}

With the rapid development of the digital economy, the traditional exhibition has accelerated the upgrading and transformation to the online exhibition. The activities of exhibition economy are not only affected by the digital economy, but under the pressure of COVID19, the traditional exhibition must speed up the transformation to the digital exhibition, and the existing online exhibitions should play the strain capacity in the new situation to meet the needs of customers. At the same time, in order to meet the needs of the market, the training of exhibition professionals should supplement the knowledge of online exhibition operation management and information technology as soon as possible.

\section{ACKNOWLEDGMENTS}

The research was supported by the general research project of Beijing Vocational College of Finance and Commerce2021: Research on transformation, upgrading and countermeasures of online exhibition under the background of digital economy (BJCZY2021C11).

\section{REFERENCES}

[1] China's digital economic development report 2020, https://www.sohu.com/a/414890242_ 100016190, visit date: January 5th, 2021

[2] GuoXinghua: "the digital economy goes up against the trend", https://baijiahao.baidu.com/s?id=16879667057751 $56999 \&$ wfr=spider\&for=pc, visit date: January 5 , 2021

[3] Zhang Maowei. The study of Regional Convention and exhibition brand building and communication strategy under the concept of "Internet plus" [J]. Journal of Guangdong Open University, 2016,25 (4): $48-54$

[4] Zhang Ziyuan. Research on exhibition marketing strategy under the background of Internet Era -Review on marketing: marketing innovation in Internet era $[\mathrm{J}]$. China Journal of radio and television, 2020 (09): 133

[5] Zheng Jiaqi. Digital transformation of "cloud based Exhibition" from Canton Fair [J]. China exhibition, 2020 (15): 56-58

[6] Li Siyi, Chen Guoqing. Based on Internet plus, the transformation and upgrading of exhibition industry in post epidemic period: [J]. business development economics, 2020 (04): 1-4

[7] Jiang Xiaoyang. Research on driving forces and Strategies of digital development of exhibition industry from the perspective of new economy [J]. Commercial exhibition economy, 2020 (12): 10-12

[8] Wu Yuwei, Liu Suhui. Research on the development of exhibition economy from the perspective of Internet $[\mathrm{J}]$. Commercial exhibition economy, 2020 (07): 5-8

[9] Tong Huabin, LvYulong. The strategy of meeting professional talents training in the context of Internet plus: taking Zhejiang agriculture and Commerce Career Academy as an example [J]. Vocational Education Forum, 2018 (8): 150-153

[10] Hu Lingxia, Xiao Shengefei. Research on the reform and Countermeasures of innovative talents training mode -- Taking exhibition planning and management major as an example. Vocational Education Forum, 2017 (11): 63-66

[11] Liu Haiying. Digitalization: the common export of online and offline exhibitions [J]. China Exhibition (China Conference), 2020 (24): 13

[12] Ye Qianqian. Research on strategic transformation of major government exhibitions to "cloud exhibitions" and countermeasures and Suggestions -- Taking "innovation fair" as an example [J]. Development research, 2020 (08): 75-84 